\title{
"ETNOGRAFIA DE UMA CATÁSTROFE ESTUDO DE ANTROPOLOGIA URBANA E VISUAL SOBRE OS DESAFIOS DA NATUREZA E A SOBREVIVÊNCIA COMO MODO DE VIDA ENTRE MORADORES DE ÁGUAS CLARAS, VIAMÃO”
}

\author{
Aline Greff Buaes \\ Cornelia Eckert (Orientação)
}

\section{Introdução}

Neste trabalho de pesquisa desenvolvo um estudo de caso sobre as experiências enfrentadas pela comunidade de Águas Claras, distrito do município de Viamão, quando de uma catástrofe natural, um princípio de ciclone acontecido em outubro do ano de 2000. Através da análise de suas narrativas busco conhecer suas interpretações sobre esta brusca ruptura da rotina. A repercussão dessa catástrofe sobre suas condições de vida, atingindo famílias e comunidades, quando correm risco de vida e perdem boa parte de seus bens materiais, é analisada a partir de suas narrativas sobre o caso, onde tecem referências identitárias de trajetórias pessoais, familiares e coletivas.

No ano de 2000, como bolsista de iniciação científica do Núcleo de Antropologia Visual (PPGAS, UFRGS) passei a desenvolver a pesquisa intitulada "Os Desafios da Natureza: estudo de antropologia urbana e visual sobre o cotidiano de sobrevivência como modo de vida na cidade". Esse estudo se desenvolve no âmbito do projeto de pesquisa individual da Profa. Dra. Cornelia Eckert, intitulado "Feições dos medos e das crises no ritmo das sociabilidades cotidianas na cidade: estudo etnográfico". Com o objetivo de estudar junto a famílias em vilas populares na "grande" Porto Alegre as experiências vividas a partir de catástrofes naturais, como inundações, ventanias, incêndios, a fim de conhecer suas narrativas sobre estas descontinuidades nas previsibilidades cotidianas.

As populações economicamente desfavorecidas estão entres as mais ameaçadas pelas tragédias provocadas pela natureza, consideradas como consequiências do desenvolvimento incontrolado dos grandes centros urbanos e dos efeitos degradantes ao ambiente no século XX. 
Acidentes ambientais ou catástrofes naturais repercutem sobre as condições de vida e sociabilidades de grupos urbanos em regiões urbanas. Nessas experiências, as imagens resgatadas pela população servem de instrumento para configurar e contextualizar o evento. As imagens anteriores ao evento os auxiliam a rememorar a vida antes da catástrofe, e algumas vezes, repensando a realidade em comparação com o antigo modo de vida. As imagens da imprensa sobre a tragédia, guardadas pelas vítimas, auxiliam na configuração de uma identidade de grupo enquanto sobrevivente de uma catástrofe natural. Essas imagens coletadas são importantes na construção das narrativas dos moradores, onde se desenvolve uma memória afetiva e coletiva.

\section{A escolha do universo de pesquisa}

"Que o fato social seja total não significa unicamente que tudo que é observado faça parte da observação; mas também e sobretudo, numa ciência que o observador é da mesma natureza que o seu objeto, o observador é ele próprio uma parte da sua observação”.(Claude Lévi-Strauss, Introdução a obra de Marcel Mauss)

Essa afirmação de Lévi-Strauss sobre a teoria do fato social total de Marcel Mauss me faz perceber que para conseguir realizar uma análise científica com cunho antropológico em cima dos dados que já havia coletado iria precisar analisar a minha própria relação com o objeto da minha pesquisa e com as teorias antropológicas que vão se fundir ao meu conhecimento acerca da comunidade que estudei.

A partir destes critérios, a escolha do universo de pesquisa foi pela localidade de Águas Claras, distrito do município de Viamão, cidade vizinha da capital do Estado, Porto Alegre. Conhecida por ter sido a primeira capital do Estado, no século XVIII, atualmente é o maior município da região metropolitana. Sua economia se baseia na agropecuária e em serviços, mas a maior parte da população trabalha na capital,

Porto Alegre. O distrito de Águas Claras é essencialmente rural, com grande produção agrícola, mas muito povoado. Com muitas áreas de sítios, a região é conhecida por sua beleza natural.

Qualquer leitor assíduo da imprensa local, soube do ocorrido em Águas Claras, Viamão em outubro de 2000, porque neste período a imprensa noticiou amplamente o fato: 
“Pessoas Feridas e Engarrafamento na RS-040, em Viamão” (Jornal Zero Hora, $12 / 10 / 2000)$

Desta forma ocorreu meu primeiro contato com o que viria a ser meu universo de pesquisa. O noticiário chamava sobretudo atenção pelos grandes apelos que faziam por doações. Necessitavam de roupas, comida e principalmente materiais de construção, pois as casas haviam sido completamente destruídas.

Nesta ocasião trabalhava em um órgão de imprensa e estava fazendo rádioescuta durante a noite quando a rádio recebeu uma primeira notícia do que havia acontecido e então o burburinho começou. Durante quase toda a noite e pelo resto da semana a rádio noticiava muito o que estava acontecendo e cumpria seu papel social de auxílio à sociedade. Reiterava os pedidos de doações da comunidade e assim mobilizava a sociedade para ajudar aquela não tão distante comunidade a sobreviver a mais um infortúnio da vida cotidiana.

Cerca de mês mais tarde, quando retornava de uma viagem ao sul do estado pela RS-040, lembro daquela região ter saltado aos meus olhos, pelas casas e prédios ainda destruídos, pelas árvores ainda caídas na beira da estrada, pelos grandes depósitos de arroz retorcidos no chão.

Três meses depois, quando da decisão de realizar um estudo sobre desastres naturais e como as comunidades enfrentavam estas situações, realizei uma triagem entre os jornais locais buscando localizar situações de enfrentamento a desastres naturais.

Nos últimos três anos este foi o caso mais impressionantemente divulgado pela mídia. O fenômeno chamou a atenção pela sua força destruidora e também pelo total descontrole por parte dos meteorologistas, que não previram nada de diferente em seus mapas.

\section{Inserção na pesquisa de campo}

Em minha primeira ida a campo, janeiro de 2001, fazendo quase quatro meses do acontecido, imaginei que não fosse encontrar ainda muitos vestígios do que passou, nem física nem psicologicamente. Então me perguntava: o que ainda poderia encontrar naquela comunidade para tratar sobre desastres naturais? 
Através da prefeitura de Viamão, que realizou um programa de construção de casas para as famílias que haviam perdido tudo, cheguei a uma família de baixa renda que teve sua casa completamente destruída pela tormenta. A família viveu durante dois meses no ginásio paroquial aguardando a construção da nova casa que a prefeitura construía. Em minha primeira entrevista com eles, estavam há apenas 15 dias na casa nova, que ainda estava em obras. Também através da prefeitura cheguei a uma das lideranças da comunidade de Águas Claras. Um dos líderes do Movimento Comitê Solidário Viamão 2000, que organizou mutirões para construções de casas, pedidos de doações para a mídia, distribuição de cestas básicas.

E através destes dois principais personagens passei a conhecer o "fenômeno" que passou por Águas Claras. Não apenas um vento que derrubou casas, mas que fez as pessoas diretamente atingidas repensarem seus modos de agirem no mundo. Por sua impressionante imprevisibilidade, "um acontecimento natural nunca visto antes no Rio Grande do Sul com tanta força" (depoimento de um morador), mostrou o quão nãodomesticada ainda é a natureza. Mesmo quase seis meses depois do acontecido, ainda encontramos latentes em suas narrativas as conseqüências, em suas vidas e em seus pensamentos, do envolvimento total com este "fenômeno". Um "fenômeno" que o estudo aponta como causa de uma construção de sentimentos de união e solidariedade entre uma comunidade, que após experienciar um momento de risco comum, buscou estratégias para reorganizar sua vida coletiva.

\section{Introdução aos personagens}

“Um fato social só é realmente total quando apreendido numa experiência concreta, de uma sociedade localizada no tempo e no espaço, mas também de um indivíduo qualquer dessas sociedades”.(Levi-Strauss -Introdução a Mauss)

A partir dessa colocação de Levi-Strauss na introdução que escreveu para o livro de Marcel Mauss, Ensaio sobre a Dádiva, percebe-se a importância de, ao analisarmos fenômenos sociais, darmos voz as pessoas envolvidas neste fenômenos, procurando ouvir não apenas suas opiniões sobre o fenômeno em si, mas também suas colocações pessoais, procurando conhecer suas próprias visões do fenômeno, onde a maneira como enfrentaram o caso, as mudanças em suas vidas cotidianas, a importância dada ao fato, são elucidativos das diferenças de trajetórias pessoais que levam a diferentes maneiras de enfrentar e interpretar o evento. 
Então, através dessas duas pessoas que, diria, estiveram por completo envolvidos neste fato, analiso suas narrativas e suas trajetórias, suas memórias e suas formas de representação dessa experiência comum.

Baltasar Molina, de origem uruguaia, mora há 19 anos em Águas Claras. Sua história pessoal está ligada com a história da comunidade, os dois cresceram juntos. Atualmente, além de um sítio na região, é dono de uma imobiliária local, e prefere trabalhar na região, ao invés do centro da cidade, pois assim não precisa cumprir horário. Gosta de vender campos, conhece todo o interior do estado e vende terras no Uruguai também. Seu trabalho sem rotina, segundo ele, torna o dia-a-dia renovante, "é ecológico, a gente vai olhando paisagens diferentes". Sobre sua liderança na comunidade, que se mostrou muito forte na ocasião desta catástrofe, afirma "não sou elegível nem elejo ninguém porque sou gringo, então sou apolítico".

Molina é grande conhecedor da comunidade. Através dele tive mais informações sobre o bairro de Beco do Lassaço, onde mora a família de Dona Neuci. O local onde se situa o Beco era uma antiga estrada. A comunidade que se formou ali são de pessoas pobres que foram se instalando há muitos anos, e estão até hoje.

Dona Neuci também é moradora da região há muitos anos e conhece bem a comunidade. Sua casa no Beco do Lassaço que foi destruída pelo vento tinha levado 12 anos para ser construída. Com o marido agricultor, o dinheiro recebido com o trabalho de cada colheita anual era investido nas despesas da casa. Ela, atualmente dona de casa, divide seu tempo entre a granja onde seu marido trabalha e a casa no Beco, onde moram os filhos e os netos. Com três filhos homens, todos trabalhando, e duas filhas, uma com treze anos ainda não trabalha, e a outra, Kelen, que também participou de algumas entrevistas. Kelen é a mãe dos netos que Dona Neuci tanto gosta. São quatro crianças lindas que tomam conta da casa.

Evangélica há mais de vinte anos, Dona Neuci é conhecida na sua comunidade como a "assistente dos doentes", como ela mesmo define. Qualquer problema que precise de socorro na cidade, Dona Neuci é sempre solicitada. Isso porque ela conhece bem Porto Alegre, sabe ir para os hospitais, conhece os trâmites do sistema de saúde pública e coisas assim. Como ela mesmo diz, "quem tem boca vai à Roma, se eu quiser ir pra São Paulo, pego o endereço e vou, porque eu tenho boca né. Fico abismada com essa gente...". 


\section{A catástrofe inserida no cotidiano}

No início da noite do dia 11 de outubro de 2000 o estado do Rio Grande do Sul foi atingido por uma onda de tormentas em locais isolados. As tormentas, em alguns locais consideradas princípios de ciclones, surpreenderam a população, já que não houve previsão alguma por parte dos meteorologistas. A massa de ar quente que se chocou com massas de ar fio provocou rajadas de vento que chegaram a $110 \mathrm{~km}$ por hora. Milhares de pessoas ficaram desabrigadas em todo o Estado. A comunidade de Águas Claras, no interior de Viamão, foi a mais atingida pelo fenômeno, nunca acontecido antes na região. Inúmeras famílias perderam suas casas durante os cinco minutos que durou a passagem do ciclone. Outras milhares tiveram suas casas parcialmente destruídas.

A passagem por uma experiência como essa, de enfrentamento a uma catástrofe natural, de tamanha extraordinariedade para o cotidiano de qualquer pessoa, acaba resultando em inúmeras maneiras de interpretar o fato real. Encontra se nas narrativas dos moradores muitos aspectos que nos mostram as idéias, teorias e simbologias próprias, que revelam as formas simbólicas com que cada pessoa se apropria para tentar compreender a catástrofe que se atravessou nas suas trajetórias. O medo comum pelo risco da morte, a total imprevisibilidade do acontecido e a sobrevivência ao caos são aspectos que são interpretados das mais diversas maneiras pelas vitimas.

Nas tentativas que os moradores da região atingida fazem de descrever o exato momento em que o desastre aconteceu, percebemos como cada um tenta contar esse momento, em que se misturavam sentimentos de surpresa e medo. Nas narrativas não há um tempo certo, as características são variáveis. Percebe-se algo de "mágico", situado "dentro e fora do tempo", conforme Victor Turner.

Victor Turner em seus estudos sobre processos rituais define esses momentos "liminares" na vida dos participantes (Turner, 1969). Momentos em que a emoção vem

a tona, em que não existe muita certeza sobre o que está acontecendo. Como percebemos neste depoimento de um morador a um repórter de jornal :

"Perdemos o raciocínio e não sei quanto tempo durou" (morador da região em depoimento a Zero Hora de 13/10/2000) 
A preocupação em descrever os aspectos fora do comum que estiveram presente durante todo o momento, desde antes do evento, aparece neste trecho de entrevista realizada com Molina:

"Era uma coisa estranha, um fenômeno estranho. Eu pessoalmente, lá em casa, tava um calor, uma coisa abafada, não se mexia uma folha. Só que tinha uma coisa que eu nunca tinha visto: relampeava toda volta, toda volta no céu, mas não era relâmpago assim de, era uma coisa tenrue, que mexia só, como essas luz fluorescente que começam a piscar assim, era assim toda volta, tava totalmente branco o céu. Aí eu estive olhando fora de casa aquilo e entrei pra dentro de casa tranqüilo, tava vendo a novela, e de repente começou a vim vento, ventinho assim, uma brisa pesada, e foi se intensificando mais o branco, e aos poucos foi aumentando o vento, começou a cair pedra, caiu assim as primeiras pedras tudo, foi uma coisa rápida, durou assim uns dois ou três minutos no máximo. Cada vez mais forte a pedra e mais forte o vento. Aí começou a voar o teto, e a gente se protegeu como podia, lá em casa não quebrou porta nem nada, levou a parte de cima do teto. E passou rápido."

Mas contrapondo essa descrição de "Seu Molina", que teve sua casa destelhada, temos o depoimento de Dona Neuci, que morava numa casa de seis quartos, "uma estância de grande" (expressão usada por ela), os dois ou três minutos do ciclone foram suficientes para destruir o sonho da casa que levou 12 anos de trabalho árduo. Mas esse aspecto é deixado de lado quando o que conta é a sobrevivência de todos na casa:

"E perdemo tudo em quatro minutos, mas eu dou graças a deus que a gente ficou tudo vivo. Porque caiu uma casa, que nem caiu em cima de nós, eu sempre digo, que a mão de deus tava aqui. Porque cai, com essas crianças tudo, essa aqui grávida de 7 meses, ela não sofreu nada, nada (...) ela tava "entocada", tinha um cantinho assim que cabia uma cadeira. Aí ela reuniu as crianças tudo, e

tava sentadinha na cadeira(...)E aí então a casa caiu toda em picadinho, pra ti ver como a mão de deus tava ali, mas aquele lugar que ela tava caiu aquele escombro inteiro nas costas dela, e o escombro ficou parecia uma gangorra. E eu disse, ela não teria força suficiente pra segurar aquele escombro. Eu digo a mão de deus tava aqui."

Esse momento crucial é apenas o começo de uma grande história. Pois esses não foram fatos isolados. Segundo dados da Defesa Civil, 1500 casas foram totalmente ou parcialmente atingidas pelo tornado na região de Águas Claras, 270 famílias perderam tudo. Uma comunidade inteira vítima de uma catástrofe nunca vista antes na região. Uma experiência totalmente nova para muitos, e uma condição comum de enfrentamento a este desastre que estava apenas começando. Primeiro a preocupação com a própria vida, depois dos familiares, depois dos vizinhos. Após tudo isso, a constatação do estrago geral deixado pela tormenta: 
"Então eu sai pra fora com um farolete, aí eu vi que tava tudo no chão, vizinhos correndo, outros gritando. No meu condomínio é de umas casas separadas, bem separadas, aí, como chovia muito pegamos umas lonas pra proteger os móveis, cama, colchão, o que se podia, eram três pessoas na minha casa. E aí foi parando, foi parando, ficou uma noite normal, noite de lua, clara, e terminando de guardar nossas coisas e daí minha esposa se lembrou dos nossos netos. (...) Aí fomos sair, quando íamos sair pela rua árvore no chão, fomos pela outra rua, árvore no chão, e eu fiquei apreensivo, a minha esposa dizendo que os netos tavam mal, e tal, aí eu digo, vamos fazer uma coisa. Peguei uma alicate e fui cortando os arames farpados, indo pelos campos, em algum lugar da estrada eu ía sair. Conseguimos sair pelos campos e já encontramos gente com motosserra, tirando árvore do caminho, e chegamos na faixa. Quando saímos na faixa era um caos total. Gente correndo pra tudo que é lado, andando de carro pra tudo que é lado, cada um procurando parentes, para um lado e para outro. E aquela quantidade de árvores caídas, aí como podíamos, chegamos. (...)Eu tô te contando o meu caso, que é o caso de todo mundo aqui. E o meu caso ainda não é o mais grave, tinha jipe, tinha noção da situação." (Depoimento de Molina sobre os momentos seguintes a tormenta).

Como Molina mesmo nos diz, seu caso está longe de ter sido o mais grave. Tinha jipe e tinha noção do que havia acontecido. Para as famílias que perderam a casa a situação foi bem diferente. No caso da família de Neuci, ela me relata que nem viu a casa cair. Ficaram todos muito atordoados e foram para casa da vizinha. Sua filha Kelen descreve que não se atinaram nem de guardar as coisas da casa. Foram para o alojamento no dia seguinte porque não tinham "uma coberta seca, um colchão onde pudessem dormir".

\section{Organização do grupo e solidariedade}

Após esses momentos traumáticos é que começara o real enfrentamento a catástrofe. As vítimas e os estragos ficaram no rastro deixado pela tormenta. As pessoas aos poucos foram percebendo o tamanho desses estragos e as dificuldades que teriam pela frente. A união nesse momento não é apenas uma vontade mas uma necessidade. Necessidade essa que pode se dar pelo lado psicológico, como afirma Kelen, filha de Dona Neuci, que explica que todos da família foram para casa da vizinha que não havia sido totalmente destruída para terem menos medo, "com mais gente por perto, o medo diminui". 
Neste depoimento de Molina também percebemos este momento de união nascendo no seio da comunidade, já que seria Molina, junto com mais alguns representantes da comunidade, que iria começar um movimento de solidariedade pelas vítimas da tormenta, que iria continuar pelos próximos três meses:

"No outro dia, de manhã cedo, fiz uma revista do que era nossa região aqui. Era tanta desolação que tinha, que a gente não sabia por onde ia começar." (Seu Molina)

O momento "liminar" começava em suas vidas. Liminar pois já não era como antes, alguma coisa teria de ser feita, o estado em que se encontravam era claramente transitório, pois aquela situação não duraria para sempre. Conforme Turner nos coloca em sua teoria, nesse momento "as pessoas não estavam mais lado a lado, mas umas com as outras". Estavam todos no mesmo "barco", um mais "afundados" que outros, mas o fato desses que não estavam tão "afundados" começarem a reação, proporcionou que todos pudessem participar dessa reação. O trecho reproduzido abaixo foi tirado de uma reportagem publicada alguns dias após o desastre e que procura mostrar o estado em que se encontrava a comunidade:

\begin{abstract}
"Uma atmosfera de incredulidade transtornava, ontem, os rostos dos habitantes do município de Viamão. Três mil moradores da cidade mais atingida pela fúria do tempo no Estado contavam apenas com uma grande aliada: a solidariedade."(Trecho de reportagem publicada em Zero Hora de 13/10/2000)
\end{abstract}

O fato de não conseguirem entender o que havia acontecido para encaixar nessa "rede de classificações" (Turner, 1969) que usamos normalmente para definir as coisas que nos acontecem propiciou o surgimento dessa "communitas espontânea". Esse termo foi usado por Turner para explicar esses momentos diferentes que as comunidades passam, onde não existe mais a "estrutura" que existia antes, e a nova estrutura, que vai se basear na antiga, ainda não se formou. Nesses momentos transitórios, surge então a "communitas", de modo "imprevisível em qualquer tempo entre seres humanos que são institucionalmente contados ou definidos como membros de algum tipo de agrupamento social"(Turner,1969).

Nesse depoimento de Molina, o sentimento de solidariedade externo ao grupo e a organização interna que nascia no grupo demostram a crença na força do movimento que surgia:

"Aquela quantidade de gente se solidarizou com nós, com a situação toda, já estava sendo noticiada em todos os jornais. E tal. Então as nossas duas famílias e mais umas 
vinte famílias se acoplaram a nós, foi um evento familiar. Então começamos a pedir material de construção, e o primeiro que pedimos foram telhas. Formamos um grupo aqui e na sexta-feira já começamos a pregar telhas, aí já tínhamos 4mil telhas mais ou menos. Repartimos as telhas, desde os auxílios mais essenciais paras as pessoas que estavam machucadas, levemente. E leite, cestas básicas, tudo que era coisa, nós saímos pra levar pras famílias, tudo nos nossos carros. E aí trabalhamos até a madrugada levando coisa pras pessoas. E pregando telhas, tu sabe que continuava a chuva né. A chuva continou por três dias. Então nós íamos levando roupa seca, de cama, que ganhamos, tudo que era ajuda, as famílias levavam pra essas pessoas. E nós tinhamos uma equipe que ia pregando telhas. Quando foi o quarto dia depois do temporal nós já tínhamos pregado cinco mil telhas. Era muita coisa! Era bastante trabalho. Todo mundo abandonou seus afazeres pra trabalhar com isso. Quando a gente chegava nas casas, as pessoas tavam deprimidas. A gente colocava teto numa peça pra eles se abrigarem e as pessoas já ficavam felizes, sabe, de uma outra maneira. Aí a gente deu muita importância pra coisa. Porque, pô, era uma coisa fundamental. Então, foi uma experiência muito grande que tivemos, todas essas famílias." (Trecho de entrevista com Baltasar Molina em 15 de março de 2001)

Para além do Comitê criado por Molina e mais alguns representantes da comunidade, inúmeros outros órgãos, como a prefeitura, o Governo do Estado, algumas Igrejas e outras instituições não-governamentais, além é claro da grande imprensa, trabalharam em prol dos desabrigados. O sentimento de união e solidariedade que tomou conta da comunidade, colocando como comunidade não apenas as vítimas da mesma catástrofe, mas, como disse Dona Neuci, o Rio Grande do Sul inteiro que se uniu. Percebemos a força dessa afirmação quando de sua descrição das doações que receberam nos momentos mais críticos:

"Foi sim uma união muito grande, tu sabe que eu nunca tinha visto um troço tão bonito que nem a união. Eu que assisti lá no salão as doação o tempo todo, foi assim, que nem eu te disse, eu entrei no salão às 5 e meia, por aí, e não tinha nada, eu comprei as primeiras coisas, mas quando foi pelas oito horas da noite, começou a chegar doação, doação, tinha que ter 3 na portaria pra recolher, por que um não dava conta, foi quantidade. (...)aquilo ali tava sempre cheio, eras umas prateleiras numa altura assim do chão, sempre cheio.(...). A gente entrou lá não tinha nada, quando foi lá por dez, onze horas da noite, o salão tava sortido de tudo. E foi, o Rio Grande do Sul inteiro se uniu."(Trecho de entrevista com Neuci em 03/05/2001)

Percebemos isso também nas afirmações da imprensa sobre o que acontecia em Águas Claras:

"Histórias de desesperança que se entrelaçam às de solidariedade" (Trecho de reportagem sobre o caso de Viamão publicado em Zero Hora de 12/11/2000) 


\section{O cotidiano marcado pela experiência da tragédia}

Se observa então que a imprevisibilidade do evento também se traduziu na "imprevisibilidade" do que surgiu depois. A nova organização da comunidade era ainda "rudimentarmente estruturada e relativamente indiferenciada" como Turner caracteriza as "communitas". Essa indiferença que é como uma consequiência da falta de estrutura. Pois, estando todos meio "perdidos", cria-se uma atmosfera de indiferença social observadas nas atitudes que se seguiram ao momento "liminar". A união que se traduziu também nas relações pessoais, o risco de vida que passou muito perto e que produziu união dentro da comunidade. A mistura de "homogeneidade e camaradagem" colocada por Turner ou, como afirma Molina, o "calor humano".

"Antigamente, as pessoas por picuinhas ficavam de mal e tal. Hoje em dia não é assim. Nós tivemos uma lição muito grande do que o ser humano deve ser. Pessoas que nem me cumprimentavam, chegavam aqui e a gente recebia elas. Porque é uma coisa maior, uma coisa diferente que aconteceu nas nossas vidas."

Nesse momento em que todos repensaram suas vidas, a maneira de compreender o que aconteceu muitas vezes implicou, como nos conta Dona Neuci, em regeneração:

\footnotetext{
"Os vizinhos aqui aconteceu uma coisa muito bonita, tu sabe. Havia pais brigados com os filhos que se uniram. Esse aí que tinha se separado da mulher, a mulher tinha ido embora pra casa do sogro, no outro dia (risadas) tavam tudo unido.(...) Aí então muitas coisas aconteceram. Aquela senhora ali, que tem uma garagem com uns letreiro de motoserra, o filho tinha brigado com ela, e ele tava parando lá na casa de uma filha, lá na subida, e lá perdeu, rachou umas paredes, e aí com aquela ficaram unidos. A Kelen e a vizinha da primeira casa de material, ali onde tem aquele banheirinho, onde nós se abrigamos depois do temporal, tinha brigado por causa das crianças. Ficaram tudo unido naquela noite. Esqueceram tudo aquilo."
}

A maneira como Dona Neuci aponta os aspectos positivos que surgiram na comunidade mostra um ideal de que este momento de "communitas" poderia continuar, se estender para o cotidiano, provocar mudanças mais significativas no dia-a-dia. Já que esses pontos mostrados por ela não costumam acontecer:

"Então, foi uma coisa de louco. Tinha gente que ia lá levar leite todos os dias, tinha outros donos de sítios que iam levar ovos, aipim, batata doce, ai, foi uma coisa muito bonita de se ver. Por isso que eu digo, devia de continuar. Ali, o Comitê Solidário, se eles continuassem isso aí, o Seu Molina conhece todo esse pessoal que ficou assim, podiam distribuir. Pras pessoas que necessitam. E tem esse pessoal de chácara que tem frutas, verduras, aipim, batata-doce, essas coisas, por que se isso continuasse,.... Tanto açougue aí, a Perdigão, às vezes mandavam buscar osso pra fazer sopa, me mandavam 10 quilos de chuletinha, que maravilha. Muita gente ajudou." 
A communitas como "especulativa e geradora de idéias e imagens filosóficas"(Turner, 1969, p.162), é exatamente o que percebemos neste momento nas narrativas dos moradores. A comunidade que se conheceu enquanto força num momento de tragédia e necessidade. Como nos coloca Molina, que acredita que a comunidade cresceu e vai continuar crescendo depois da experiência que tiveram:

"O positivo foi esse calor humano apresentado esse tempo todo, com certeza vai se transformar numa união mais grande pra essa comunidade se projetar no futuro. Por que surgiram coisas aqui. Por exemplo, a gente tava meio abandonado de Viamão e das autoridades, com esse calor humano que se formou aqui, se formaram grupos, gente, apareceram líderes que estão agora lutando e demonstrando pras autoridades públicas que aqui há também uma força política. Que é uma força nova, que não tinha né. Agora há uma força política. Esse vento ajudou Águas Claras a se projetar em outros planos."

$\mathrm{Na}$ visão de Victor Turner, o desenvolvimento das sociedades passa pelas situações de "communitas". Para ele, após serem "libertados da estrutura" nos momentos liminares os homens retornam para a estrutura revitalizados pela experiência da "communitas". Os fatos considerados bons que aconteceram durante o processo de reconstrução da comunidade criaram um desejo de continuação entre os moradores. $\mathrm{O}$ ideal de comunidade surge pelos fatos considerados bons, pelas coisas que não costumam acontecer no dia-a-dia. O cotidiano é a "estrutura" de suas vidas, cheia de "dificuldades objetivas, pragmático e mundano" (Turner, 1969, p.170). A "communitas ideológica", conforme coloca Turner, funciona como uma "anti-estrutura". As comunidades menos favorecidas que se sentiram mais cidadãs, as autoridades que se preocuparam com elas, a mídia que as colocou nas manchetes, as instituições e organizações não-governamentais, religiosas e não religiosas, que investiram na reconstrução. Tudo isso pode ter levado a um crescimento da comunidade, como afirmou Molina, mas levou também a um reconhecimento da comunidade enquanto tal.

O distrito de Águas Claras é composto por bairros muito separados fisicamente e heterogêneos, alguns mais isolados, uns mais agrícolas, outros mais residenciais, outros de "periferia". Por um instante, "a sociedade e os homens tomaram consciência sentimental de si próprios e da sua situação frente a frente", como Marcel Mauss coloca em sua conclusão do Ensaio sobre a Dádiva.

Neste estudo sobre a obrigação de dar e receber entre alguns povos primitivos, Mauss faz considerações importantes sobre a presença destas obrigações em nossas sociedades contemporâneas: 
"Uma parte considerável da nossa moral e da nossa própria vida permanece sempre nesta mesma atmosfera da dádiva, da obrigação e ao mesmo tempo da liberdade. Felizmente nem tudo está ainda classificado em termos de compra e venda. Restam-nos pessoas e classes que mantém ainda os costumes de antigamente e quase todos nós nos sujeitamos a eles, pelo menos em certas ocasiões ou épocas do ano." (Marcel Mauss, Ensaio Sobre a Dádiva, p.185)

A ocasião de um desastre natural com conseqüência trágicas para muitas famílias, trouxe a tona esses sentimentos aos quais Mauss se refere. As doações que aconteceram envolveram "categorias" de pessoas muitos distantes, a ajuda para os desabrigados incluiu desde os vizinhos de Dona Neuci, que estavam em situação quase igual a dela, até, por exemplo, a Igreja Mórmon Internacional, que fez doações de milhares de dólares. Então, esse "fato social total" envolveu inúmeras instituições, das mais variadas origens, com um único objetivo: os indivíduos. $\mathrm{O}$ sentimento de obrigação de dádiva que surge num momento de tragédia, tragédia essa que poderia acontecer em qualquer lugar em qualquer tempo. A imprevisibilidade do fenômeno natural pegou a todos de surpresa. A solidariedade que surgiu no seio dessa comunidade e se espalhou também surgiu de maneira imprevisível e se mostrou fundamental para a sobrevivência do grupo.

O caso de Dona Neuci foi dos mais sérios de Águas Claras. Com a casa completamente destruída, ela e sua família, passaram dois meses morando no ginásio paroquial com mais algumas famílias. Mesmo tendo passado péssimos momentos nesse tempo, ela nos mostra o quanto sabe sobre a obrigação de dar e receber. Nesses dois meses viveu de donativos. Como pertencente a Igreja Evangélica há mais de vinte anos e extremamente fiel a Jesus, segundo ela mesmo, suas associações sobre os fatos da vida sempre levam a agradecer a Deus. Ao afirmar que a união continuou por muito tempo, ela nos ilustra com uma história que aconteceu com ela e nos mostra, depois de tudo por que passou, o significado de um provérbio maori citado por Mauss segundo o que ele defende para nossas sociedades:

"Dá tanto quanto recebes e tudo estará bem":

"Nós viemos do salão, essa casa aqui já tava o corpo todo pronto, e foi no natal, tem uma neguinha que para ali, aquilo me cortou o coração, ela passou aqui na frente, e foi até ali adiante e sentou debaixo duma árvore. Foi muito duro, no dia do natal a pessoa não ter senão uma árvore pra se agasalhar. Eu tinha tirado ela porque ela vinha aí se engalinhar quando tava só os guris na barraca, eu dizia que isso aqui não é cabaret mesmo. Ai, depois que eu tirei ela, eu fiquei com pena dela e mandei minha guria ir chamar ela. Tu sabe que deus foi tão bom, que eu disse pra ela quando eu recolhi: eu te recolho aqui, te dou roupa, comida, te dou tudo, só que eu não quero coisa com os meus guri,(...) fica xarope tu fica aí e ficar dando em cima dos guris, aí ela concordou. Ai recolhi ela, e depois de meia hora que eu dei o aviso pra ela, deus nos mandou um sustento, pra ti ver como são as coisas. Chegou um senhor aí com um baita de um 
sacolão, com rancho, café, com tudo, bastante coisa. E deus mandou tudo pra mim suprir ela. Aí nós fomos lá na faixa comprar uma carne pra assar, e aí o senhor lá da faixa mandou dizer que tinha umas coisa pra nós lá, e nós viemos, era uns 40 quilos de osso, carnudo, viemos nós três, sem brincadeira, a Neuza com um saco, eu com um sacolão, a guria atrás de mim. Como nós não tinha geladeira, tava sem luz ainda, não tinha como guardar, a metade acabou indo fora. Eu disse como são as coisas de deus, deus mandou ela mas mandou sustento também. Aí assim eu sempre recolho né."

Mas ela também tem a sua própria maneira, com as devidas associações religiosas, de dizer mais ou menos o mesmo princípio: "Deus primeiro dá a tarefa, se tu fizer a tarefa, ele te dá a recompensa". E com esse princípio ela acaba regendo a sua própria vida, mesmo em fatos que aconteceram antes da tragédia, como esse por ela relatado:

"Tudo que é correria que tem fazer aqui no Beco, é comigo, porque senão ninguém sai, porque ninguém conhece Porto Alegre, ninguém isso, ninguém aquilo. Meu deus do céu. E eu sempre faço. Porque é um Dom que deus deu pra gente, e não adianta. E as recompensa de deus são maravilhosa, bah, quando eu fiquei com aquela guriazinha desse senhor aí, lá era dura a pegada, porque eu tinha que ir pro hospital, pegar a sobrinha, trazer pra rodoviária, e voltar pro hospital, porque ela não sabia, não atinava em ir pra rodoviária sozinha. Aí fiquei um mês. Aí eu disse pro meu marido, certamente deus tem alguma coisa pra nos dar. Porque primeiro ele dá a tarefa, se tu fizer a tarefa, ele te dá a recompensa. E tu sabe, que um dia nós tava sentado, meu marido tava desempregado, aí eu tava falando com ele se ele conseguisse um serviço ele daria o dízimo do salário dele. E ele nunca teve tão bem, em quatro anos. Quando nós acabamos de concordar com o dízimo, nós tava sentado na cama, na frente da janela, aí passou uma rural, aí eu disse, que engraçado, isso aí tá com cheiro de chumbeado, que é o patrão que tem lá em morungava. E aí, o homem parou e chamou o Juarez, fez um sinal pra gente. Fomo lá. Naquela época, o homem ofereceu 1300 real pro Juarez trabalhar pra ele, quatro anos trás. Aí eram dois sócios, e o outro quis parar e conversar. E aí conversaram, conversaram, ele foi pra lá e eu trabalhei também lá. E aí ele foi prá lá ganhando mil reais por mês. E foi a recompensa que deus deu."

\title{
Interpretações do imprevisível
}

\author{
"o que eles não estavam dispostos a fazer era simplesmente abandonar \\ qualquer hipótese, deixar os acontecimentos simplesmente acontecerem." \\ (Geertz,1979, p. 116)
}

Nesse comentário, Cliford Geertz fala sobre a constante busca de explicações entre seus informantes para os fenômenos que ameaçavam permanecer "opacos", inexplicáveis, afirmando o fato de eles não deixarem de acreditar em sua suposições, pois precisavam de suas crenças para explicar para eles mesmos os fenômenos, colocando esses fenômenos dentro do "esquema de coisas aceitáveis". Em seus estudos sobre religião, Geertz afirma que muitos homens, provavelmente a maioria, quando têm ameaçada a sua capacidade analítica frente a acontecimentos não 
totalmente encaixáveis no "esquema de coisas aceitáveis", tendem a formular algumas "noções sobre a maneira como tais aspectos podem coadunar-se com seus experimentos mais comuns"(Geertz, p. 115.,1979). A necessidade de uma explicação para os fatos surge da necessidade humana de tentar compreender o mundo em que vivemos e a maneira como estamos inseridos nele. Neste contexto que surge o desafio que as religiões se propõem.

Nas narrativas dos moradores de Águas Claras, a questão das interpretações próprias criadas por eles surge da falta de uma explicação científica para o fato. Os centros de previsão meteorológica do Rio Grande do Sul não conseguiram prever o ciclone que passou pela região, e mesmo depois do fato, seus técnicos afirmaram ser praticamente impossível com a tecnologia existente atualmente a previsão de um fenômeno como aquele. A questão da imprevisibilidade do que aconteceu levou a busca de interpretações das mais variadas. Mas também a questão da catástrofe, do caos, que produziu medo nas pessoas, e que levou a apropriações simbólicas de cunho não-lógico ou irracional. Ou seja, explicações sobrenaturais para o acontecido, que se apoiavam especialmente sobre as crenças religiosas.

Neste trecho retirado de uma reportagem publicada dias depois da tragédia, o discurso jornalístico incorpora o discurso nativo:

"Rita, o marido, o pedreiro Cláudio Gil Pereira, 38 anos, e o filho Leonardo, de oito, escondiam-se embaixo de uma mesa, enquanto o vento arrastava a 40 metros, uma camioneta Jeep que ficaria emborcada num barranco, ao lado da RS-040. O tornado preferiu transformar a casa de Rita num amontoado. No outro dia, ela olhava o monturo de meio metro de altura. Como conseguiram sair vivos, sem um arranhão, se até a mesa era parte dos destroços?" (A Noite dos Desesperados, Zero Hora 15 de outubro de 2000)

A sobrevivência ao caos é um dos aspectos que mais encontramos nas narrativas. Nos depoimentos de Dona Neuci encontra-se muito presente esse elemento sobrenatural, para além da "fronteira relativamente demarcada do conhecimento acreditado"(Geertz,1979,p.117). Para muitos fatos relacionados com a tragédia, a presença de "Deus" ou "Jesus" é constante e também a questão para ela "milagrosa" da família inteira, com todas as crianças ter sobrevivido. Quando relata o momento da tragédia, por exemplo, ela afirma que "a mão de Deus estava ali", como que "segurando as paredes". A crença em sua fé a faz ter certeza de que foi Deus que salvou sua vida e 
de toda a família. Essa maneira de encarar os acontecimentos foi a interpretação que Dona Neuci criou, sua própria maneira de tentar compreender o que aconteceu e assim obter uma explicação.

A essência da ação religiosa, segundo Geertz, dentro de um ponto de vista analítico, é atribuir a um certo complexo específico de símbolos uma autoridade persuasiva. Essa autoridade reconhecemos no discurso de Dona Neuci na figura de Deus. O poder de permitir a ação do diabo, e assim, a ocorrência da catástrofe. O poder de decidir sobre o destino das pessoas e salvar a vida de todos. Numa de nossas conversas, ela me citou uma parte da Bíblia onde diz que não é Deus que cria as coisas ruins. É o diabo, mas é Deus que permite a ação do diabo. Por isso, ela afirma que foi que Deus que salvou a vida de todo mundo ali na comunidade de Beco do Lassaço, local onde ela mora e que foi o mais atingido pela tormenta. Me questionou como será no fim do mundo se naquela noite já foi um pavor. No fim do mundo não restará nada, ela mesma afirma.

Neuci também relacionou a história mítica da Arca de Noé com a tragédia de Viamão. "Noé ficou duzentos anos avisando as pessoas que o mundo ia acabar e ninguém acreditava. E o mundo acabou mesmo." No caso de Viamão, o mundo não acabou naquela noite, mas chegou muito perto, na visão de alguns moradores. Em outro trecho retirado da mesma reportagem citada acima, percebe-se novamente a incorporação do discurso nativo e a analogia com mitos apocalípticos:

\footnotetext{
"Quanto tempo dura o horror? Por quanto tempo as mulheres e as crianças conviveram com a ameaça do fim do mundo na noite de quarta-feira nas localidades de Águas Claras, Boa Vista e Entrada das Lombas, em Viamão?” (A Noite dos Desesperados, Zero Hora 15 de outubro de 2000)
}

A apropriação destes símbolos religiosos nas narrativas dos moradores é uma forma que buscam para compreender o que se passou em suas vidas. Mas também torna-se uma "garantia cósmica", segundo Geertz, para definirem seus sentimentos e assim conseguirem suportá-los. Dona Neuci perdeu tudo que tinha, mas o fato de não ter perdido sua família, é a prova de que um "milagre" aconteceu naquela noite. Em seus depoimentos, percebe-se que isso diminui a dor das outras perdas, as perdas materiais que teve. Uma de suas vizinhas conta que nos dias seguintes a tormenta as pessoas que passavam pela frente dos destroços não conseguiam acreditar que ninguém tivesse morrido naquelas casas. Também a gravidez da filha, que estava de sete meses no dia da tormenta, e que não sofreu nada, tanto que o neto nasceu dois meses depois com a saúde perfeita, é uma prova de um milagre para ela. Em outra declaração de um 
morador da mesma região ao jornal Zero Hora percebe-se esses mesmos elementos religiosos aliados a força do recomeço após a tragédia:

"Deus não quis matar meus filhos. Isso dá coragem pra recomeçar."

Observa-se que o uso de mitos e outros símbolos religiosos para compreender os fatos leva a uma compreensão de mundo baseada numa ordem "cosmológica". Cosmologia entendendo-se como um "esquema interpretativo à disposição do sujeito que conhece o mundo e age sobre ele" (Aracy Lopes da Silva,1982, p75), orientando, dando sentido e permitindo interpretar acontecimentos. A "garantia cósmica" surge também dessas teorias sobre o mundo. As pessoas sentem necessidade de entenderem mais sobre o universo, sobre as forças que estão agindo. As religiões entram nesse sentido de dar uma ordem ao mundo, "às ambigüidades percebidas, aos enigmas e paradoxos da experiência humana"(Geertz, 1979, p124). Por isso o apoio tão grande que as vítimas dessa catástrofe encontraram na Igreja. Os símbolos da religião dando sentido ao acontecimento, mesmo que esse sentido muitas vezes tenha uma ligação mínima com a realidade. Mas, como Geertz afirmou, tudo que eles não queriam era abandonarem suas crenças, deixando os acontecimentos simplesmente acontecerem.

Mas existe também outro aspecto nas interpretações de Dona Neuci que a levam a fazer associações muito fortes, afirmando a falta de fé dos vizinhos que tiveram as casas destruídas pelo vento.

A antropóloga americana Mary Douglas se dedicou aos estudos do que ela chama de "crenças de poluição". Poluição num sentido daquilo que ofende a ordem. Seguindo a linha de Durkeim, Douglas afirma que "as crenças religiosas expressam a consciência que a sociedade tem de si mesma; a estrutura social é creditada com poderes punitivos que a mantém existente” (Douglas, 1966, p.126). Nessa visão, a ordem social é preservada através de "perigos" que ameaçam os transgressores. "As crenças de poluição sustentam a ordem moral" (Douglas, 1966, p.140).

Ao comparar a existência das "crenças de poluição" nos povos antigos e nas sociedades contemporâneas, ela afirma que ambos estão sujeitos as mesmas regras, mas que nos "povos primitivos" elas são mais amplas e fortes; nas sociedades atuais se aplicam a áreas de existência deslocadas e separadas. Para Douglas, no pensamento primitivo todo "desastre natural era carregado de significado"(Douglas,1982,p33), e isso levava a uma idéia de "natureza politizada", onde em todo pequeno infortúnio havia 
um dedo de culpa. Logicamente, o pensamento contemporâneo não deveria absorver estas "crenças de poluição" visto que a natureza hoje já é vista como "moralmente neutra", graças aos avanços científicos que nos permitem ter essa visão.

No pensamento primitivo a natureza era politizada pela comum invenção de misteriosas conexões entre transgressões morais e desastres naturais, segundo Mary Douglas. Nas narrativas de Dona Neuci encontramos essas conexões muito presentes. Quando afirma que seu marido e seus vizinhos não iam a Igreja com ela, afirma também que a falta de fé deles pode ter levado a essa catástrofe:

\footnotetext{
"Meu marido fazia um mês que eu chamava pra ir na igreja, e convidava "Vamo Juarez", eu acho que eu tava ditando que ia acontecer uma coisa dessas. A Mara, eu dizia "Vamo na igreja Mara", e a Mara que nada. Aí, quando ele viu, eu sempre, desde do ventinho que deu, eu clamo muito por Jesus né, então eu gritava por socorro pra Jesus né, daí ele, no desespero, ele dizia Socorro Jesus, e eu dizia pra ele: Bah, mas não precisava cair uma casa pra ti pedir socorro pra Jesus, porque eu te chamei antes pra ti ir pra Igreja. Um mês antes eu já dizia pra ele, Juarez vamo na igreja, e ele debochava da minha cara e dizia: Olha onde vai o Juarez, vai na Igreja. E naquele dia ele viu como.(...) a gente pode passar por certas coisas que acontecem pra gente se acordar do mundo."
}

Transgressões morais para serem associadas aos desastres podem ser de naturezas diversas. Mas esses elos entre infortúnios e pessoas, segundo Douglas, são sempre pessoais. A vizinha "Mara", segundo Dona Neuci, havia brigado com o marido dias antes do temporal. Depois do desastre começou a freqüentar a Igreja. Para Dona

Neuci isso é motivo de criticas. Mas, segundo ela, muitas pessoas da comunidade só foram a Igreja nos dias que se seguiram ao desastre. Em sua visão, é muito importante as pessoas terem fé em alguma Igreja. Essa visão pessoal dela, de uma pessoa crente na sua religião que acha que todos devem ter uma religião, é uma visão pessoal que se insere numa visão universal. $\mathrm{O}$ universo torna-se pessoal em vários sentidos, segundo Mary Douglas, “as forças físicas são consideradas entrelaçadas com as vidas das pessoas e as pessoas não são distintas do seu ambiente externo. O universo reage ao discurso e à mímica. Discerne a ordem e intervém para mantê-la.”(Douglas, 1966, p110) Nessa visão, Neuci enxerga essa catástrofe como um sinal de que as coisas não estavam certas, havia algo de errado. Algo ou alguém havia cruzado a fronteira do moral e do imoral. As pessoas sem fé e que não iam a Igreja, podem ter sido as coisas erradas na comunidade, eram as "poluições perigosas", que colocaram em perigo todos na comunidade. 
Mas nas interpretações de Dona Neuci que envolvem outras transgressões morais, ela mesma acaba se colocando no lugar de "poluidora". Como no caso do vizinho dono de um bar:

\begin{abstract}
"...meu vizinho aí ele explorava muitos, e eu cansei de pedir pra Deus derrubar o buteco dele, pra ele não explorar mais ninguém, e aí deus deu a coisa repartida né, caiu o buteco e caiu minha casa também. (risadas) Quando eu me lembrava eu ria. Um dia, eu me lembrando e falando pro Everton, e ele me disse: Pois é, mãe, não quis te falar, esses dia tava me lembrando, quanto vezes tu pedia pra Deus derrubar o buteco. Mas ele fazia uma cachaçada, minha nossa, e faz, agora ele montou um balcão ali de novo. Então a vida dele é viver de exploração, e eu ficava louca da vida, porque os guri iam pra lá, era (...), era dinheiro dos encachaçados, chegava 5 e meia era aquela bicharada de conta pra pagar, tudo por conta de quê, do buteco."
\end{abstract}

A construção de Dona Neuci envolve algo como "uma autoridade judicial ao incidente da desgraça"( Douglas,1982,p35), conforme Mary Douglas. Autoridade essa, que nesse caso, é dada a Deus, que repartiu o castigo. Pois a própria Neuci enxerga a sua culpa quando pediu para derrubar a casa do vizinho. Ele era o transgressor, o imoral, mas ela também transgrediu os limites. Neuci também conta do dinheiro que esse vizinho tinha escondido no forro da casa onde funcionava o bar e que no dia da tormenta, quando o telhado foi destruído, saiu voando. Conta que nos dias seguintes as crianças encontravam notas de dez reais por toda a região.

Ou seja, o vizinho perdeu todo o dinheiro, além de ter perdido a casa. Assim seu castigo pode ter sido maior do que o de Neuci.

Nesse caso está acontecendo, conforme afirmaria Douglas, uma "cadeia causal de ações a desastres"( Douglas,1982,p.36), onde categorias de pessoas são mantidas separadas, para que outras possam ficar juntas. As categorias físicas são sustentadas pelas crenças de poluição, que sustentam categorias conceituais dividindo o moral do imoral e assim sustentando a visão da sociedade perfeita., afirma Douglas.

Quando afirma que o vizinho vivia de explorar os outros, Neuci coloca ele numa categoria de "imoral". Separa ele da sua família, colocando assim que a casa dele caiu porque ela pediu, porque Deus realizou a vontade dela. O fato da casa dela ter caído também, ela interpreta como uma conseqüência, pois o castigo foi dividido.

As crenças de poluição são baseadas também em um "problema social interno sobre culpa e inocência" conclui Mary Douglas. A narrativa de Dona Neuci incorpora muito desses elementos de culpa e inocência. Por exemplo, quando afirma que estava tentando levar o marido e a vizinha Mara à Igreja um mês antes da tragédia, "eu acho 
que eu tava ditando que ia acontecer uma coisa dessas". A absolvição seria dada assim pela fé em Deus. Na visão de Neuci, se todos tivessem ido a Igreja, talvez Deus não tivesse permitido o Diabo agir naquela noite. Também o "vizinho explorador", que se não fosse tão explorador, não ia fazer com que ela pedisse a Deus para derrubar seu bar.

As "conexões misteriosas" feitas pelas vítimas são também parte desse processo de culpa ou absolvição, segundo Douglas. A maneira como as pessoas vem a acreditar nessas conexões é deixada de lado pela teoria das crenças de poluição, que afirma também que "os censores de uma comunidade possuem suas próprias crenças de poluição e teorias causais". Dona Neuci nesse estudo é apresentada como um censor da comunidade. Não se estudou aqui se os outros membros da comunidade acreditam em suas teorias ou não. $\mathrm{O}$ que se percebe aqui é sua capacidade de criação dessas teorias causais. Onde todos os fatos se conectam. Onde um motivo, ou vários motivos, se apresentam para explicar o porquê da tragédia ter acontecido com eles, naquela comunidade, naquele dia. Fatos anteriores ao acontecido, que talvez na época não tivessem importância, agora, depois da tragédia, voltam a memória e entram nas narrativas como fatores causais.

O processo de culpa se mostra na procura de um "culpado". Alguém que tenha ultrapassado as fronteiras do código moral, os limites socialmente aceitáveis. Dona Neuci encontra então em seu vizinho, dono de um bar, alguém que ultrapassou esses limites. Fica claro aqui o elo pessoal nessa crença de poluição. Os clientes do bar que faziam barulho a madrugada inteira e assim incomodavam a vizinha Neuci. Sentindo-se incomodada ela pede a Deus para derrubar o bar, num ato de desabafo. Quando esse bar caiu, assim como a sua própria casa e de toda a vizinhança, esses fatos são todos relacionados na montagem de uma teoria que explique o fenômeno da tragédia. Também o caso da vizinha Mara, que também perdeu a casa e teve seus móveis encontrados a centenas de metros do local da casa. Nesse caso, Neuci relaciona a briga de Mara com o marido dias antes do temporal, e também o fato de ela não freqüentar a Igreja.

Dentro dessas conexões misteriosas sem motivo aparente encontradas na narrativa de Dona Neuci, percebemos também uma confusão "entre suas experiências subjetivas e objetivas”(Douglas, 1966, p.110). A analogia da tragédia causada pela tormenta de outubro com outros fatos trágicos da vida pessoal dela é realizada sem nenhum motivo lógico aparente. Quando analisava fotos da casa que possuía antes do temporal, recordava de como era a casa, e de como gostava dela, e também das pessoas 
que estavam presentes na época e apareciam nas fotos:

\begin{abstract}
"Porque nós tiramos uma quantidade de fotos, parecia que nós ia advinhar que aquilo ia ficar de recordação.(...) Acho que nós tava advinhando, nós tiramos um monte de foto da casa, e a minha netinha que faleceu. Quando nós ia advinhar que nós ia perder ela, porque a mãe dela foi embora pra Cachoeirinha e levou ela, e nós ficamos com as fotos dela, porque ela faleceu lá, a coisa mais linda.(...) Aí eu olhando, mas que engraçado, nós tava advinhando que nós ia ficar sem a nossa casa véia."
\end{abstract}

\title{
Foto, casa antiga e neta
}

A história da neta que faleceu algum tempo antes da tragédia do temporal é recordada neste momento. Sua outra neta mulher, hoje com dois anos, a mesma idade com que faleceu a outra neta, é sua neta preferida hoje e através dela relembra dos outros fatos e realiza novamente "conexões misteriosas" na busca de uma explicação:

\begin{abstract}
"E as vezes eu fico mal, e digo pra Jesus: Ah Jesus, eu não posso morrer hein. (risadas) Agora eu digo pra Jesus que eu não posso morrer antes da Madalena se criar porque a Kélen é muito apegada nesses dois pequenos, mas os dois grandes ela não se liga. Essa aqui mesmo... (e aponta para a menina no seu colo). A outra faleceu e essa aqui nasceu. Aí a Kelen implicou com essa aqui. Não teve amor nunca por essa aqui. Agora ela fingi, tu vê ela pegar, abraçar. Mas tu vê que não é aquele amor. Porque ela ficou muito traumatizada com a outra que faleceu no mesmo dia do nascimento dessa aqui. Quer dizer, a outra se enterrou dez e meia da manhã, essa aqui nasceu seis horas da tarde. Ela criou a Madalena assim com um desamor, é até agora.”
\end{abstract}

Essas conexões feitas por Neuci são relacionadas de alguma maneira com a tragédia do temporal. A busca por uma teoria que explique a morte dessa criança, mostra que esse fato ainda não foi totalmente compreendido por Neuci. A mistura das experiências objetivas com as subjetivas cria uma certa confusão, confusão essa colocada por Douglas como "necessária e universal na passagem do caótico para o individual"(Douglas, 1966, p.110). Sua visão de mundo não lhe permitia compreender a morte da neta. Mas, em "respostas a problemas práticos particulares"(Douglas, 1966, p.112) essa visão de mundo, e também de universo, vai se alterando e se adaptando, sempre na busca de interpretar os fatos. Ao afirmar que deve criar a neta que está viva, pois a filha não tem condições, coloca para si a responsabilidade, e assim pede para Jesus para não morrer. Acredita que cuidando da neta que está viva, não perderá ela, assim como perdeu a outra. O trauma sobre a filha Kelen, mãe das duas meninas, também é uma questão que Neuci aborda para justificar o porquê dela ser a responsável pela criação da neta. 
Novamente aqui uma "conexão misteriosa", nos termos de Douglas, e uma "teoria causal” criada por Dona Neuci, mas com base em fatos reais. Ou seja, a criação no pensamento de Dona Neuci não é gratuito. Douglas coloca em outro momento sobre os fatos reais:

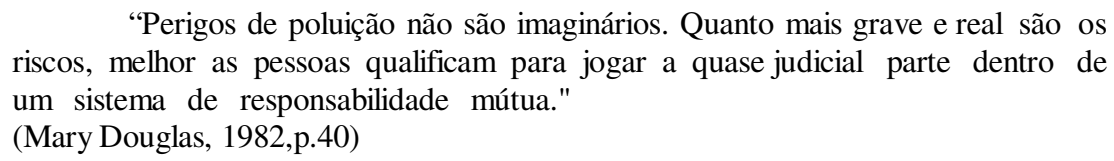

"Perigos de poluição não são imaginários. Quanto mais grave e real são os riscos, melhor as pessoas qualificam para jogar a quase judicial parte dentro de um sistema de responsabilidade mútua."

(Mary Douglas, 1982,p.40)

Não se compreende muito bem o porque dela afirmar que a filha não ama a própria filha, mas percebe-se o processo de culpa sobre a filha Kelen acerca da morte da neta. Esse processo acredito que surge do medo que Neuci tem de perder a neta viva. Por isso traz para si a responsabilidade de criá-la. E coloca novamente numa figura religiosa, Jesus, a autoridade e o poder de decisão sobre os fatos. Novamente aqui a "garantia cósmica" que nos falou Geertz, onde os símbolos religiosos dão precisão aos nossos sentimentos, permitindo suportá-los. A existência de alguém que esteja lá em cima olhando por nós é a certeza de que não estamos "perdidos num mundo absurdo...'(Geertz,1979,p.117).

\section{REFERÊNCIAS}

DOUGLAS, Mary. Pureza e Perigo. São Paulo, Perspectiva, 1966.

DOUGLAS, Mary and Wildavsky, Aaron. Risk and Culture. Los Angeles, University of California Press. 1982.

GEERTZ, Clifford. A Interpretação das Culturas. Rio de janeiro, Zahar, 1979.

MAUSS, Marcel. Ensaio Sobre a Dádiva - Introdução de Claude Lévi-Strauss

TURNER, Victor. O Processo Ritual. Petrópolis, Vozes, 1974.

SILVA, Aracy Lopes da. Mitos e Cosmologias Indígenas no Brasil: Breve Introdução. In: Grupioni, Luis (org.).Índios no Brasil. Brasília, Ministério da Educação e do Desporto, 1994.

Reportagens de Arquivo

MEMÓRIA RBS - Arquivo Zero Hora 